\title{
Haemodynamic studies in veno-occlusive disease of the liver
}

\author{
T. E. KASTURI, S. C. MANCHANDA, R. K. TANDON, M. RAJANI, AND \\ M. L. BHATIA
}

From the Departments of Cardiology, Gastroenterology, and Radiology, All India Institute of Medical Sciences, Ansari Nagar, New Delhi, India

SUMMARY Haemodynamic studies in 8 tribal patients from central India with veno-occlusive disease of the liver are reported. The disease was caused by eating cereals contaminated with seeds of a crotalaria species rich in toxic pyrrolizidine alkaloids similar to monocrotaline and fulvine.

All patients showed raised hepatic venous wedge pressures and pressure gradients between hepatic venous wedge and free hepatic vein. Significant pressure gradients were also observed in the inferior vena cava. Right and left heart pressures were normal. Cardiac and stroke indices and ventricular work were significantly increased while systemic and pulmonary resistances were reduced. Hepatic blood flow was also reduced. Hepatic venograms were abnormal and the changes correlated well with the pressure gradients between hepatic venous wedge and free hepatic vein and with the histological changes in the liver.

Veno-occlusive disease of the liver in man caused by drinking concoctions prepared from indigenous plants containing pyrrolizidine alkaloids was described in detail by Bras et al. (1954) and Stuart and Bras (1957) from the West Indies. Minor outbreaks have also been reported by Willmot and Robertson (1920), Selzer and Parker (1951), Savvina (1952), and Braginskii and Bobokhodzhaev (1965). Outbreaks of veno-occlusive disease of the liver occurred recently in a tribal community of Central India and were caused by contamination of the staple cereal food with the seeds of a species of crotalaria, rich in toxic pyrrolizidine alkaloids similar to monocrotaline and fulvine (Tandon

Received for publication 24 Ja nuary 1978 et al., 1976). We were able to study 8 of these patients and describe their circulatory haemodynamics and hepatic venographic features. To our knowledge similar data have not been previously reported in English.

\section{Subjects and methods}

The 8 patients with venoocclusive disease of the liver ( 5 male and 3 female) were aged from 12 to 50 years (average 27 years) (Table 1). All presented with a history of pain in the epigastrium followed by rapid distension of the abdomen. All had significant ascites and 5 also had oedema of the feet. Mild jaundice was present in only 1 patient. The liver and spleen were palpable in 6

Table 1 Clinical features of veno-occlusive disease of liver

\begin{tabular}{|c|c|c|c|c|c|c|c|}
\hline \multirow[t]{2}{*}{ Case no. } & \multirow[t]{2}{*}{ Age (y) } & \multirow[t]{2}{*}{$\operatorname{Sex}$} & \multicolumn{5}{|c|}{ Physical examination } \\
\hline & & & faundice & Oedema & Ascites & $\begin{array}{l}\text { Liver } \\
\text { (cm beloro costal margin) }\end{array}$ & $\begin{array}{l}\text { Spleen } \\
\text { (cm below costal margin) }\end{array}$ \\
\hline $\begin{array}{l}1 \\
2 \\
3 \\
4 \\
5 \\
6 \\
7 \\
8\end{array}$ & $\begin{array}{l}24 \\
16 \\
25 \\
12 \\
20 \\
35 \\
30 \\
50\end{array}$ & $\begin{array}{l}\mathbf{F} \\
\mathbf{F} \\
\mathbf{M} \\
\mathbf{M} \\
\mathbf{M} \\
\mathbf{F} \\
\mathbf{M} \\
\mathbf{M}\end{array}$ & $\begin{array}{l}\text { Present } \\
\text { Absent } \\
\text { Absent } \\
\text { Absent } \\
\text { Absent } \\
\text { Absent } \\
\text { Absent } \\
\text { Absent }\end{array}$ & $\begin{array}{l}\text { Absent } \\
\text { Absent } \\
\text { Moderate } \\
\text { Moderate } \\
\text { Absent } \\
\text { Mild } \\
\text { Mild } \\
\text { Mild }\end{array}$ & $\begin{array}{l}\text { Mild } \\
\text { Moderate } \\
\text { Moderate } \\
\text { Moderate } \\
\text { Severe } \\
\text { Severe } \\
\text { Moderate } \\
\text { Moderate }\end{array}$ & $\begin{array}{l}4 \cdot 0 \\
5 \cdot 0 \\
6 \cdot 0 \\
4 \cdot 0 \\
\text { Not palpable } \\
\text { Not palpable } \\
3 \cdot 0 \\
3 \cdot 5\end{array}$ & $\begin{array}{l}1.0 \\
1.0 \\
1.0 \\
1.5 \\
\text { Not palpable } \\
\text { Not palpable } \\
1.0 \\
1.5\end{array}$ \\
\hline
\end{tabular}


Table 2 Liver function tests in veno-occlusive disease of liver

\begin{tabular}{|c|c|c|c|c|c|c|c|c|}
\hline Case no. & $\begin{array}{l}\text { Bilirubin } \\
(\mu \mathrm{mol} / \mathrm{l})\end{array}$ & $\begin{array}{l}\text { Total protein } \\
(g / l)\end{array}$ & $\begin{array}{l}\text { Albumin } \\
(\mathrm{g} / \mathrm{l})\end{array}$ & $\begin{array}{l}\text { Globulin } \\
(g / l)\end{array}$ & $\begin{array}{l}\text { Alkaline phosphatase } \\
\text { (KA units) }\end{array}$ & $\begin{array}{l}\text { AST } \\
\text { (SGOT)† } \\
\text { (Karmen units }\end{array}$ & $\begin{array}{l}A L T \\
(S G P T) \dagger \\
s)\end{array}$ & $\begin{array}{l}\text { Sulphobromophthalein } \\
\text { retention (\%) }\end{array}$ \\
\hline $\begin{array}{l}1 \\
2 \\
3 \\
4 \\
5 \\
6 \\
7 \\
8\end{array}$ & $\begin{array}{r}51 \cdot 3 \\
10 \cdot 3 \\
18 \cdot 8 \\
17 \cdot 1 \\
23 \cdot 9 \\
12 \cdot 0 \\
5 \cdot 1 \\
10.3\end{array}$ & $\begin{array}{l}74 \\
70 \\
74 \\
74 \\
63 \\
51 \\
72 \\
76\end{array}$ & $\begin{array}{l}18 \\
18 \\
18 \\
18 \\
26 \\
25 \\
35 \\
32\end{array}$ & $\begin{array}{l}56 \\
52 \\
56 \\
56 \\
37 \\
26 \\
37 \\
44\end{array}$ & $\begin{array}{r}18.0 \\
16.0 \\
25.0 \\
28.0 \\
8.0 \\
8.0 \\
8.0 \\
7.0\end{array}$ & $\begin{array}{r}60 \\
90 \\
80 \\
70 \\
55 \\
100 \\
40 \\
30\end{array}$ & $\begin{array}{l}35 \\
50 \\
80 \\
35 \\
30 \\
60 \\
32 \\
28\end{array}$ & $\begin{array}{r}6 \\
3 \\
15 \\
4 \\
30 \\
35 \\
20 \\
4\end{array}$ \\
\hline
\end{tabular}

AST, serum aspartate aminotransferase; ALT, serum alanine aminotransferase.

*Conversion factor for bilirubin: $1 \mu \mathrm{mol} / 1 \approx 0.058 \mathrm{mg} / 100 \mathrm{ml}$.

†Normal ranges: AST 40 units or less, ALT 35 units or less.

patients. There was no history of fever or bleeding from the gastrointestinal tract. None of the patients had clinical features of a hyperdynamic circulation. Of the 8 patients, 1 died 15 months after the onset of symptoms. The others recovered partially or completely.

Liver function tests (Table 2) showed lowered serum albumin and relatively high serum globulin levels. There was an abnormal sulphobromophthalein retention $(>5 \%)$ in 5 of the 8 patients. Serum alkaline phosphatase levels were increased in 4 patients. Serum bilirubin was slightly increased in 3 patients. Serum aspartate aminotransferase (AST; SGOT) and serum alanine aminotransferase (ALT; SGPT) concentrations were slightly or moderately increased in all the patients.

Percutaneous liver biopsy showed almost identical changes in all patients. There were large areas of centrilobar haemorrhagic necrosis. The central

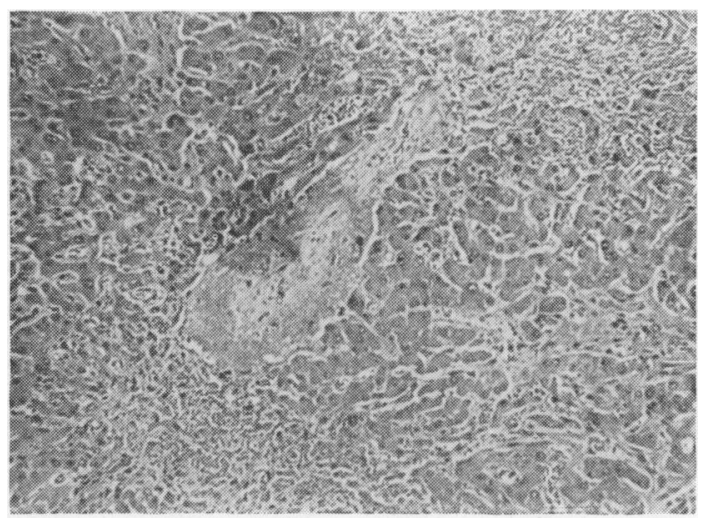

Fig. 1 Liver biopsy from a patient with veno-occlusive disease of the liver. $A$ centrilobular venous radicle is seen obliterated by proliferating fibroblasts and collagenous bundles. (H. and $E . \times 440$.) vein was usually not recognisable, and in the biopsy specimens in which it was identified it was dilated and empty but invariably surrounded by sinusoids distended with blood. There was diffuse parenchymal injury and collagenisation of the sinusoids, and the reticulin framework showed collapse and duplication (Fig. 1). None of the livers was cirrhotic.

Right heart catheterisation was carried out in the postabsorptive resting state in the supine position under light sedation (diazepam, $5 \mathrm{mg}$ ) using standard techniques. Informed written consent was obtained in all patients. The right brachial artery was cannulated for recording arterial pressure and dye dilution curves. Intracardiac pressures were recorded through Statham P23 AA pressure transducers on a 4-channel direct writing ink jet recorder (Elema-Schonander Mingograph). Baseline for all pressure measurements was mid-thorax (Roy et al., 1957). Cardiac output was determined by the indicator dilution method (Hamilton et al., 1932) from continuously recorded curves using a Colson's cuvette densitometer and a constant flow syringe with Evans Blue dye ( $5 \mathrm{mg}$ ) as the indicator. Vascular resistance, stroke index, and external left ventricular stroke work were calculated using standard formulae.

Hepatic venous wedge angiography after a hand injection of the contrast material and free hepatic vein angiography after pressure injection of Conray 420 were carried out in 4 patients. An inferior vena caval angiogram was also obtained in 1 patient. Hepatic blood flow was measured using indocyanine green dye in 4 patients (Caesar et al., 1961). Free hepatic venous angiograms were graded according to the classification of Smith et al. (1971) which is as follows:

Grade I: Normal. Smoothly tapered hepatic veins with regular branches so that at least fifth order branching is demonstrated.

Grade II: Minimal loss of tar aring and branching; sinusoidal filling is often normal. 
Table 3 Haemodynamic features of veno-occlusive disease of liver

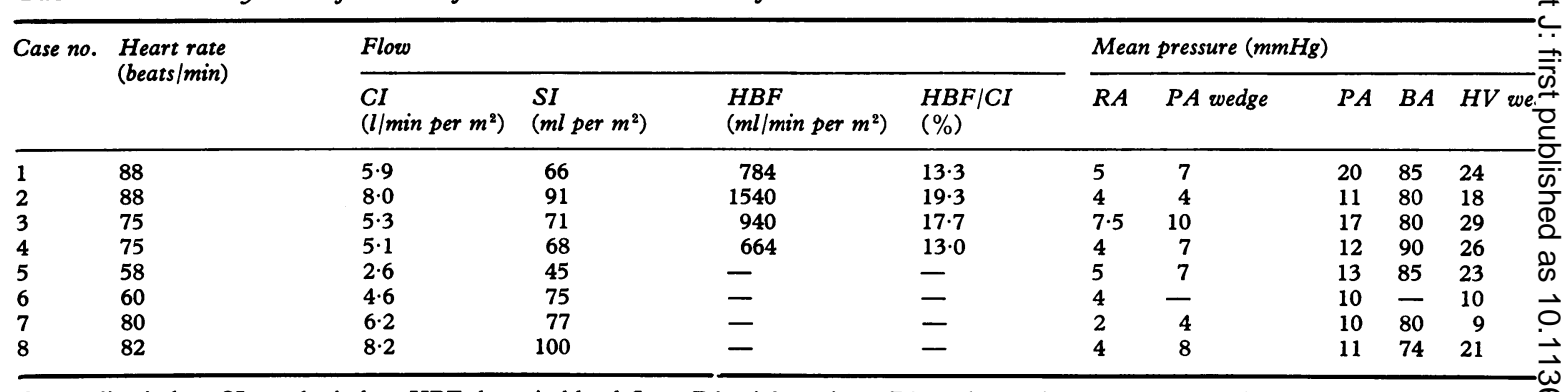

CI, cardiac index; SI, stroke index; HBF, hepatic blood flow; RA, right atrium; PA wedge, pulmonary artery wedge; PA, pulmonary artery; $\bigcirc$ brachial artery; HV wedge, hepatic venous wedge; HV, free hepatic vein; IVC, inferior vena cava; SVR, systemic vascular resistance; PVR, pulmo vascular resistance; HVR, hepatic vascular resistance; LVSWI, left ventricular stroke work index; LVWI, left ventricular work index.

$\star^{\star}$ Changes in hepatic vein wedge angiogram described in text (Smith et al., 1971).

Grade III: Clear cut loss of branching, tapering, and sinusoidal filling.

Grade IV: Branching and tapering greatly reduced. Sinusoidal filling may still be present.

Grade $V$ : Almost complete obliteration of hepatic venous system with no sinusoidal filling.

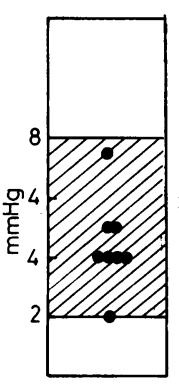

$\overline{\mathrm{RA}}$

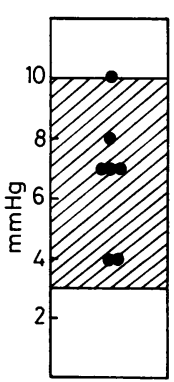

$\overline{\text { PAW }}$

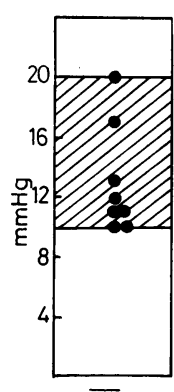

$\overline{\mathrm{PA}}$

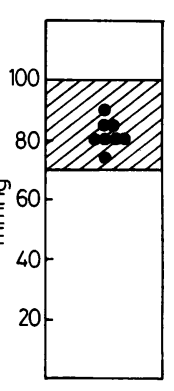

$\overline{\mathrm{BA}}$
Fig. 2 Mean right atrial $(\overline{R A})$, pulmonary arterial wedge $(\overline{P A W})$, pulmonary arterial $(\overline{P A})$, and brachial arterial $(\overline{B A})$ pressures were within normal range in patients with veno-occlusive disease of the liver. (Shaded areas denote normal pressures.)
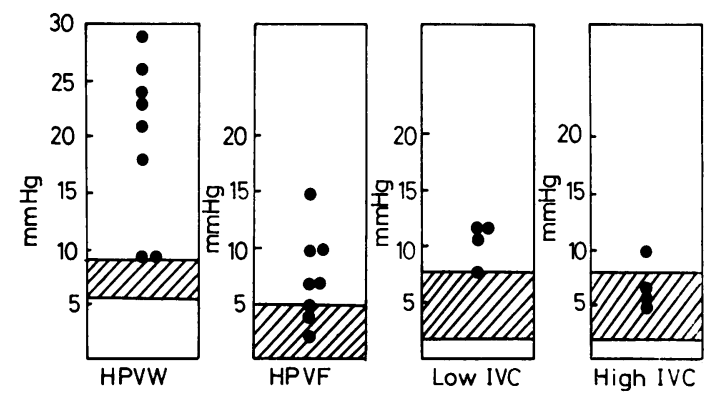

Fig. 3 Mean hepatic venous wedge (HPVW), free hepatic vein (HPVF), and low inferior vena cava (IVC) pressures were raised in most patients, but high inferior vena caval pressures were usually normal.

\section{Results}

The haemodynamic data are presented in Table 3.

PRESSURes (Table 3, Fig. 2 and 3)

Pressures obtained from the right atrium, right ventricle, pulmonary artery, pulmonary artery wedge, and brachial artery were within the normal range. Hepatic venous wedge pressures were, however, raised in all patients and ranged from 9 to $29 \mathrm{mmHg}$. Since the free hepatic vein pressure ranged from 3 to $15 \mathrm{mmHg}$, there was a significant pressure gradient between the hepatic venous wedge and free hepatic vein ranging from 5 to $19 \mathrm{mmHg}$. In 4 patients in whom inferior vena caval pressures were recorded, there was a pressure gradient between low and high inferior vena cava varying from 2.0 to $6.5 \mathrm{mmHg}$. In 2 patients, there was a significant pressure gradient between the free hepatic vein and inferior vena cava (4.0 and 5.0 $\mathrm{mmHg}$, respectively).

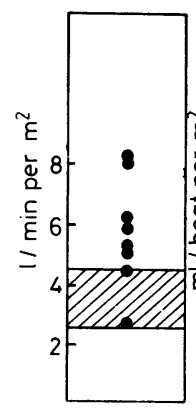

Cl

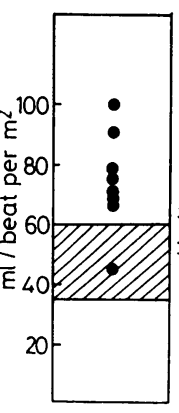

SI

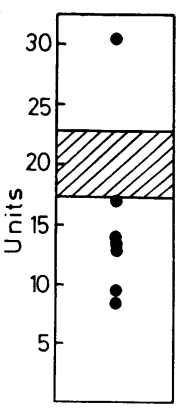

SVR

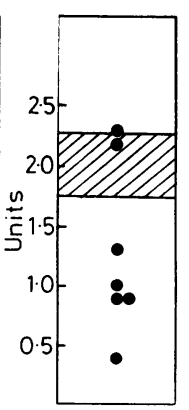

$P V R$
Fig. 4 Cardiac $(C I)$ and stroke indices $(S I)$ were raised and the systemic (SVR) and pulmonary vascular resistances $(P V R)$ were decreased in most patients. 


\begin{tabular}{|c|c|c|c|c|c|c|c|c|}
\hline \multirow[b]{2}{*}{$\begin{array}{l}\text { IVC } \\
\text { Low }\end{array}$} & \multirow[b]{2}{*}{$\begin{array}{l}\text { IVC } \\
\text { High }\end{array}$} & \multicolumn{3}{|c|}{ Resistance (units $\times m^{2}$ ) } & \multicolumn{2}{|l|}{ Work } & \multicolumn{2}{|l|}{ Angiogram } \\
\hline & & $S V R$ & $P V R$ & $H V R$ & $\begin{array}{l}L V W I \\
\left(k g \mathrm{~m} / \mathrm{min} \text { per } \mathrm{m}^{2}\right)\end{array}$ & $\begin{array}{l}\text { LVSWI } \\
\left(g \mathrm{~m} / \text { beat per } m^{2}\right)\end{array}$ & $H V$ & $H V$ wedge* \\
\hline 11 & $6 \cdot 5$ & 13.6 & $2 \cdot 2$ & 0.8 & $7 \cdot 7$ & 88 & Grade III & Moderate \\
\hline 8 & 5 & $9 \cdot 5$ & 0.9 & 0.4 & $11 \cdot 5$ & 131 & Grade III & Mild \\
\hline 12 & 10 & $13 \cdot 8$ & $1 \cdot 3$ & 0.5 & $6 \cdot 4$ & 85 & Grade IV & Severe \\
\hline 12 & $5 \cdot 5$ & 16.9 & $1 \cdot 0$ & 0.8 & $7 \cdot 1$ & 95 & Grade IV & Severe \\
\hline- & - & $30 \cdot 7$ & $2 \cdot 3$ & - & $3 \cdot 7$ & 64 & - & - \\
\hline 9 & 4 & - & - & - & - & - & - & - \\
\hline - & - & $13 \cdot 6$ & $1 \cdot 0$ & - & $9 \cdot 4$ & 118 & - & - \\
\hline - & - & $13 \cdot 9$ & 0.4 & - & $4 \cdot 1$ & 148 & - & - \\
\hline
\end{tabular}

FLows (Table 3, Fig. 4)

The systemic arterial oxygen saturation varied from 93 to 95 per cent. Cardiac index ranged from 2.6 to $8.2 \mathrm{l} / \mathrm{min}$ per $\mathrm{m}^{2}$ and was higher than normal (more than $4.51 / \mathrm{min}$ per $\mathrm{m}^{2}$ ) in 7 of the 8 patients. Since the heart rate was normal, the calculated stroke index was high.

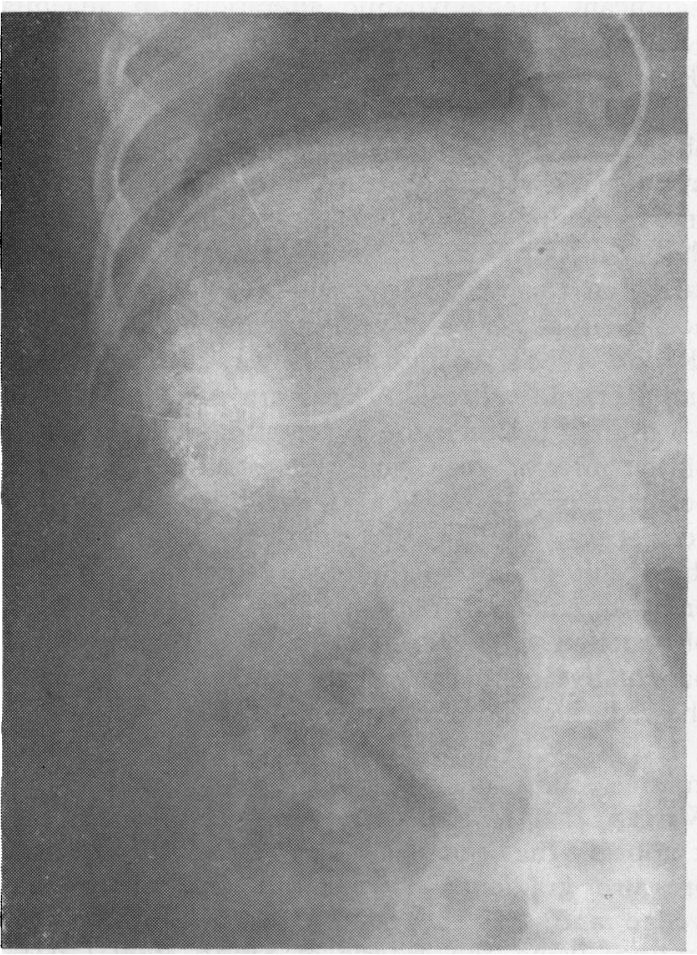

Fig. 5 Hepatic venous wedge angiogram showing a very coarse nodular pattern of the sinusoids.
RESISTANCE (Table 3)

The calculated systemic vascular resistance was low, ranging from 9.5 to 16.9 units $\times \mathrm{m}^{2}$ in 6 patients. Pulmonary vascular resistance ranged from 0.4 to 2.3 units $\times \mathrm{m}^{2}$, and was 1.0 or less in 4 patients.

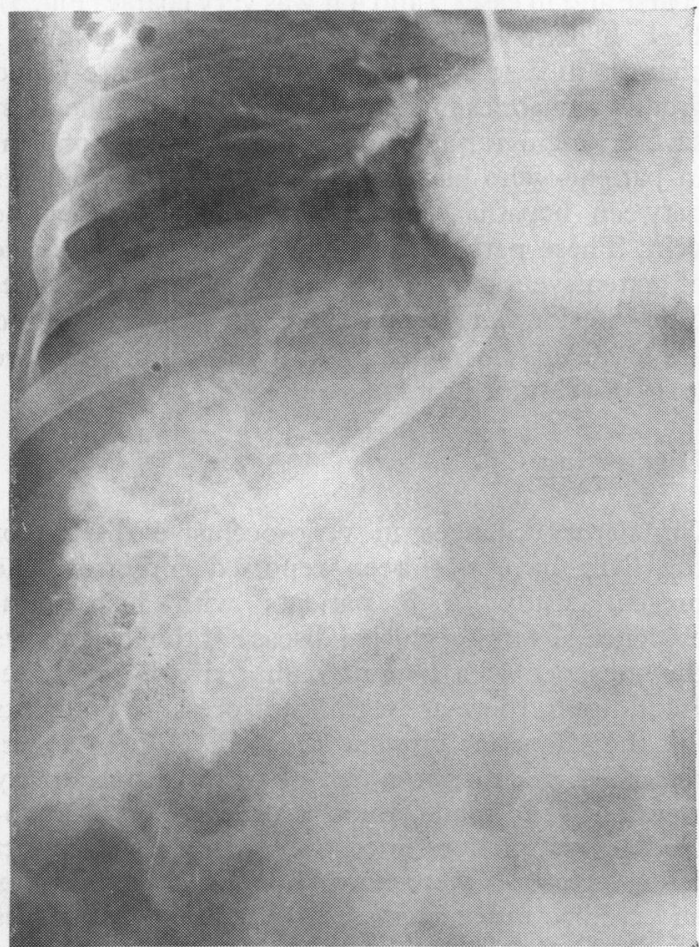

Fig. 6 Free hepatic vein angiogram showing grade II changes with distinct loss of branching of the hepatic veins. 
LEFT VENTRICULAR WORK (Table 3)

Calculated left ventricular external work index was increased in 6 of the 7 patients in whom the data were available and ranged from 3.7 to $11.5 \mathrm{~kg}$ $\mathrm{m} / \mathrm{min}$ per $\mathrm{m}^{2}$. Stroke work index varied from $64 \cdot 2$ to $148 \cdot 2 \mathrm{~g} \mathrm{~m} /$ beat per $\mathrm{m}^{2}$.

\section{HEPATIC BLOOD FLOW AND ANGIOGRAPHY} (Table 3, Fig. 5 and 6)

Hepatic blood flow measurements were made in 4 patients. Effective hepatic blood flow was reduced in 3 and normal in 1 patient (normal: mean 1210 $\mathrm{ml} / \mathrm{min}$ per $\mathrm{m}^{2}$, range 1750 to $1960 \mathrm{ml} / \mathrm{min}$ per $\mathrm{m}^{2}$ ). Hepatic blood flow expressed as a percentage of cardiac output was low in all (normal: mean 32\%, range 28 to $36 \%$ ). Hepatic vascular resistance was raised in 2 patients (cases 1 and 4) (normal: mean 0.47 units, range 0.40 to 0.59 units).

Hepatic vein wedge angiograms showed reversal of flow in the portal system as described in the early stages of portal cirrhosis (Smith et al., 1971). A fine nodular pattern of sinusoids was noted in case 2 in whom there was a small pressure gradient between the hepatic venous wedge and free hepatic vein. In case 1 , the nodular pattern was moderately coarse and in cases 3 and 4 it was very coarse (Fig. 5). Free hepatic vein angiograms showed grade II changes in case 2, grade III changes in case 1 , and grade IV changes in cases 3 and 4 (Fig. 6). The most severe angiographic abnormalities were present in patients who had the largest pressure gradients between hepatic venous wedge and free hepatic vein. These patients also had histological evidence of extensive scarring indicating advanced disease. The inferior vena caval angiogram in case 1 showed a significant narrowing of the vein lumen at the level of the ninth thoracic vertebra.

\section{Discussion}

Circulatory changes in veno-occlusive disease of the liver have not been reported hitherto. The present study in 8 patients with histological evidence of veno-occlusive disease of the liver shows the presence of a hyperdynamic circulatory state. In addition, there are significant pressure gradients in the hepatic circulatory bed. Furthermore, though direct measurement of cardiac contractility have not been made, there is no evidence of myocardial dysfunction since the right and left heart filling pressures were normal and the stroke index and cardiac index increased. Cardiac abnormalities have not been shown histologically in veno-occlusive disease of the liver (Bras and Hill, 1956); this finding is consistent with the present haemodynamic observations. The hyperdynamic circulatory state was not clinically evident, but no explanation was found for this discrepancy.

While the toxic agent causing veno-occlusive disease of the liver has been identified as a pyrrolizidine alkaloid similar to monocrotaline and fulvine (Tandon et al., 1976), the mechanism responsible for the high cardiac output in this disorder is not clear. McLean (1970) has shown experimentally that pyrrolizidine alkaloids can cause toxic injury to the hepatic veins and also cause pulmonary lesions. However, no data are available on the effect of these alkaloids on the other regional circulatory beds. One possible explanation for our findings is that the alkaloids may directly dilate the systemic vascular bed, which may in turn increase the cardiac output, but there are no experimental data to support such a concept. Mechanisms suggested to explain the high cardiac output state in other forms of liver disease, such as cirrhosis (Krook, 1956; Heinemann, 1960; Knauer and Lowe, 1967; Iwatsuki and Reynolds, 1973), may also be operative in veno-occlusive disease of the liver. Anaemia as a contributory factor can be ruled out in our patients as their haemoglobin levels were more than $10 \mathrm{~g} / \mathrm{dl}$ and significant haemodynamic alterations in anaemia occur only at haemoglobin levels of $8 \mathrm{~g} / \mathrm{dl}$ or less (Roy et al., 1963).

Pressure gradients of 8.0 to $19.0 \mathrm{mmHg}$ were observed between the hepatic wedge position and free hepatic vein. These are abnormal (Lundbergh and Strandell, 1973) but the findings are unlike those in portal cirrhosis where the pressure is raised in the hepatic venous wedge position but normal in the hepatic vein and inferior vena cava (Krook, 1956; Knauer and Lowe, 1967; Iwatsuki and Reynolds, 1973). A pressure gradient of 2 to $6.5 \mathrm{mmHg}$ between the lower and upper segment of the inferior vena cava suggests that the venoocclusive process could also extend into the inferior vena cava, though the gradient could also be the result of obstruction by thrombus formation or by an enlarged congested liver. The presence of obstruction, whatever its cause, was confirmed in 1 patient by an inferior vena caval angiogram which showed a significant narrowing of the lumen.

Hepatic vein angiograms are reported to be useful in the study of portal cirrhosis (Piper, 1961; Warren et al., 1967). In veno-occlusive disease, it appears that there is a correlation between the pressure gradients between the hepatic venous wedge and free hepatic vein, the angiographic findings using the criteria of Smith et al. (1971), and the histo jogical changes in the liver. Thus, in patients wit $h$ small gradients, the angiographic abnormalities were mild or moderate while in those 
with higher gradients the angiographic and histopathological abnormalities were severe. The severity of these abnormalities may be dependent upon the amount of toxin ingested and perhaps also the pre-existing nutritional status.

Effective hepatic blood flow was reduced in 3 of the 4 patients in whom measurements were made, while the hepatic vascular resistance was increased in 2 of them. This may indicate a major intrahepatic shunting around the affected vessels. The variable findings may result from different degrees of involvement of hepatic veins and sinusoids. These observations need to be confirmed in a larger number of patients with veno-occlusive disease.

\section{References}

Braginskii, B. M., and Bobokhodzhaev, I. (1965). Clinical picture of heptomegalia of heliotropic origin (in Russian). Klinicheskaia Meditsina, 43, 42-45.

Bras, G., and Hill, K. R. (1956). Veno-occlusive disease of the liver: essential pathology. Lancet, 2, 161-163.

Bras, G., Jelliffe, D. B., and Stuart, K. L. (1954). Venoocclusive disease of liver with nonportal type of cirrhosis occurring in Jamaica. Archives of Pathology, 57, 285-300.

Caesar, J., Shaldon, S., Chiandussi, L., Gulvera, L., and Sherlock, S. (1961). Use of indocyanine green in the measurement of hepatic blood flow and as a test of hepatic function. Clinical Science, 21, 43-57.

Hamilton, W. F., Moore, J. W., Kinsman, J. H., and Spurling, R. G. (1932). Studies on circulation. IV. Further analysis of the injection method, and of changes in haemodynamics under physiological and pathological conditions. American fournal of Physiology, 99, 534-551.

Heinemann, H. O. (1960). Respiration and circulation in patients with portal cirrhosis of the liver. Circulation, 22, 154-159.

Iwatsuki, S., and Reynolds, T. B. (1973). Effect of raised intraabdominal pressure on hepatic hemodynamics in patients with chronic liver disease and portal hypertension. Gastroenterolngy, 65, 294-299
Knauer, C. M., and Lowe, H. M. (1967). Hemodynamics in the cirrhoic patient during parecentesis. New England Fournal of Medicine, 276, 491-496.

Krook, H. (1956). Circulatory studies in liver cirrhosis. Acta Medica Scandinavica, Suppl. 318, 6-160.

Lundbergh, P., and Strandell, T. (1973). The effect of physical exercise on wedged and free hepatic venous pressure in normal man. Acta Medica Scandinavica, 194, 211-214.

McLean, E. K. (1970). The toxic actions of pyrrolizidine (Senecio) alkaloids. Pharmacological Reviews, 22, 429-483.

Piper, D. W. (1961). A radiographic study of the portal and hepatic venous system in cirrhosis of liver. American Fournal of Digestive Diseases, 6, 499-510.

Roy, S. B., Bhatia, M. L., Mathur, V. S., and Virmani, S. (1963). Hemodynamic effects of chronic severe anaemia. Circulation, 28, 346-356.

Roy, S. B., Gadboys, H. L., and Dow, J. W. (1957). Base line for left heart catheterization. American Heart fournal, 54, 753-765.

Savvina, K. I. (1952). Pathological anatomy of atrophic hepatic cirrhosis (in Russian). Arkhiv Patologii, 14, 65-70.

Selzer, G., and Parker, R. G. F. (1951). Senecio poisoning exhibiting as Chiari's syndrome. American Fournal of Pathology, 27, 885-907.

Smith, G. W., Westgaard, T., and Björn-Hansen, R. (1971). Hepatic venous angiography in evaluation of cirrhosis of the liver. Annals of Surgery, 173, 469-480.

Stuart, K. L., and Bras, G. (1957). Veno-occlusive disease of the liver. Quarterly fournal of Medicine, 26, 291-315.

Tandon, B. N., Tandon, R. K., Tandon, H. D., Narndranathan, N., and Joshi, Y. K. (1976). An epidemic of venoocclusive disease of liver in Central India. Lancet, 2, 271-272.

Warren, W. D., Fomon, J. J., Viamonte, H., and Zeppa, R. (1967). Preoperative assessment of portal hypertension. Annals of Surgery, 165, 999-1012.

Willmot, F. C., and Robertson, G. W. (1920). Senecio disease or cirrhosis of the liver due to senecine poisoning. Lancet, 2, 848-849.

Requests for reprints to Professor M. L. Bhatia, Department of Cardiology, All India Institute of Medical Sciences, N ew Delhi-110016, India. 